\title{
Håndtering af muslimske praksisser i danske folkeskoler: Autoritet, inklusion og religion
}

\author{
Sidsel Vive Jensen
}

\begin{abstract}
The Danish public debate on Islam is often concerned with the ways in which Islam is governed in Danish institutions. This article describes - on the basis of survey and interview data from schools across the country - why and how Muslim practices are governed in Danish public schools. The article demonstrates that governance of Muslim practices is not an either-or question of authority. Rather, two types of governance are identified on basis of the collected data: inclusive and exclusive governance. Inclusive governance is generally developed in schools with a high concentration of Muslim pupils. Exclusive governance is slightly more developed in schools where 'specialists' (e.g. consultants or counsellors) have been involved in the process of developing schools' governance than in schools where no specialists have been involved. Surprisingly, head teachers' perceptions of Islam and religion have no direct influence on the kind of governance developed.
\end{abstract}

Den danske debat er fyldt med holdninger til, hvordan muslimske praksisser $^{1}$ som $\mathrm{fx}$ faste og bøn skal håndteres i Danmark og særligt $\mathrm{i}$ offentlige institutioner. Ikke mindst fordi der ikke er nogen lovgivning på området, flyder medierne over med eksempler på 'afsløringer' af fx børnehaver og hospitaler, der undgår frikadeller eller serverer halalslagtet kød af hensyn til muslimske børn og patienter (Ekstra Bladet 15. og 21. juli 2013). Bekymrede debattører hævder, at muslimers ret til religiøs frihed krænkes, mens andre ligeså bekymrede debattører hævder, at danske traditioner står for fald, fordi der tages et overdrevent hensyn til en religiøs minoritet. Faktum er, at ingen har overblik over, hvordan muslimske praksisser rent faktisk håndteres i de danske institutioner, der ikke har ministerielle retningslinjer for området.

Folkeskolen er et eksempel på en institution, der ikke er underlagt nationale bestemmelser i forhold til religiøse minoriteters praksis. Der har hidtil hersket politisk uvilje imod at regulere området - særligt markeret af tidligere integrationsminister Bertel Haarders udsagn om, at han ikke er minister for leverpostej, tørklæder eller badeforhæng ( $f x$ gengivet i Information 14. juni 2003). Således er det op til den enkelte kommune eller skole at afgøre, hvordan man eksempelvis konkret håndterer halalmad. I denne artikel præsenteres resultater fra et studie, der har til formål netop at undersøge, hvordan og hvorfor håndteringen af muslimske praksisser udvikles forskelligt i danske folkeskoler.

\footnotetext{
1 Jeg bruger her 'muslimsk praksis' som deskriptiv samlebetegnelse for alle aktiviteter, der knyttes til islam, særligt i en diaspora kontekst. Det vil sige, at jeg med 'muslimsk praksis' refererer både til det at faste, at bære tørklæde, at komme i en moske etc., selvom jeg anerkender, at muslimsk praksis kan være meget andet end disse eksplicitte aktiviteter, jf. fx Jeldtoft 2012.
} 
I den europæiske islamforskning har der gennem de seneste årtier været et øget fokus på de europæiske majoritetssamfunds reaktioner på tilstedeværelsen af muslimer (Sunier 2009). Denne del af islamforskningen interesserer sig mindre for de muslimske minoriteters religiøse praksis, organisering, transformation og forgreninger og mere for fremstillingen af muslimer og islam i medier og offentlige debatter og behandlingen af religiøse minoriteters rettigheder generelt. Det centrale omdrejningspunkt er således ikke islam og muslimer, men de europæiske samfund selv; deres institutionelle organisering, deres politiske kultur, deres historiske forhold til religion og islam, og deres fremherskende ideologier om forholdet mellem religion og stat. Nærværende studie skriver sig ind $\mathrm{i}$ en forholdsvis ny niche i dette felt, som beskæftiger sig specifikt med europæiske staters håndtering af islam (Maussen 2007, Bader 2007). ${ }^{2}$

Forskningen i europæiske landes håndtering af islam søger at beskrive de vilkår, som forskellige sammenhænge etablerer for islam og muslimer, og forklare baggrundene for disse forskellige vilkårs etablering. Håndteringen af islam består konkret i tilpasning til, regulering, imødekommelse eller afvisning af forskellige aspekter af islam som $\mathrm{fx}$ bygning af moskeer, særlige indrejsetilladelser til imamer og forsyningen af halalmad $\mathrm{i}$ offentlige institutioner. I beskrivelsen af håndteringen af islam skelner man mellem forskellige aktørers (muslimer og ikkemuslimer) indflydelse (Bader 2007) og forskellige samfundsmæssige niveauer: det internationale, nationale, regionale og lokale (Rath et al. 2001, Bowen 2007). Blandt forklaringerne på forskellige håndteringer af islam, der indtil videre er fremhævet $\mathrm{i}$ forskningen, indgår både de ressourcer og muligheder for påvirkning, som muslimerne i den konkrete sammenhæng har, og de ideologiske eller strukturelle kendetegn ved majoritetssamfundet (Tatari 2009) som fx en generel afvisning af religion i kraft af fransk sekularisme (Liederman 2000, Mannitz 2004), eller det særlige forhold mellem kirke og stat i Tyskland (Mannitz 2004, Fetzer og Soper 2005).

I dansk sammenhæng er der indtil videre ikke lavet studier, som specifikt fokuserer på håndtering af islam eller muslimske praksisser hverken lokalt eller nationalt. Det betyder ikke, at der ikke er lavet undersøgelser af forholdet mellem islam/muslimer og danske institutioner generelt eller folkeskolen specifikt. Forskningen vedrørende islam og skoler har primært beskæftiget sig med undervisningen $\mathrm{i}$ kristenkundskab, og hvordan islam behandles i denne undervisning ( $\mathrm{fx}$ Jensen 1994, Olesen 1987 og Buchardt 2008) eller med de muslimske friskoler (Ihle 2007, Shakoor 2008). Der er også forsket i, hvordan islam diskursivt fremstilles i skolen, og på hvilken måde nogle muslimske børn fremhæver islam som en signifikant identitetsmarkør i skolen (Moldenhawer 2001, Gilliam 2009). Selvom der også er lavet beskrivelser

\footnotetext{
2 Bader og Maussen benytter termen 'governance of Islam' om det brede felt af mulige håndteringer af Islam, som både kan være styrende og imødekommende, og som kan leveres af både interne (muslimer) og eksterne (repræsentanter for majoritetssamfundet) aktører. Denne brug af termen 'governance' adskiller sig fra den Foucault-inspirerede brug, der mere snævert vedrører styring, og jeg oversætter derfor governance til 'håndtering' frem for 'styring'.
} 
af, hvordan forholdet mere generelt er mellem skole og religion ( $\mathrm{fx}$ Andersen et al. 2006), har der manglet et specifikt fokus på religiøs praksis i skolen. Med perspektivet fra den europæiske forskning i håndtering af islam sættes der $\mathrm{i}$ denne artikel fokus på, hvordan muslimske praksisser håndteres $\mathrm{i}$ skolen, og på de bagvedliggende strukturelle og ideologiske forhold om religion og skole, der er betydningsfulde for, hvordan skolernes håndtering er udviklet.

\section{Datagrundlag}

Studiet bygger på både interview- og spørgeskemamateriale indsamlet fra folkeskoler på tværs af Danmark i 2011. Spørgeskemaundersøgelsen består af svar fra 409 folkeskoleledere ud af de på det tidspunkt ca. 1.500 folkeskoler. ${ }^{3}$ På 286 af de 409 skoler, der deltog i undersøgelsen, er der elever med muslimsk baggrund, og det er i sagens natur disse skoler, undersøgelsen tager udgangspunkt $\mathrm{i}^{4}{ }^{4}$ De spørgsmål, der er stillet til skolelederne, vedrører deres skoles håndtering af muslimske praksisser, hvem der har haft indflydelse på udviklingen af denne håndtering, samt skoleledernes forhold til religion generelt og til islam specifikt.

De udvalgte muslimske praksisser, der spørges til, er halalmad, faste, bøn, højtider, tørklæde og kontakt til moske/imam. Disse praksisser er udvalgt i et forsøg på at operationalisere 'islam' via formelle islamiske praksisser (som bøn og faste) og meget synlige (i hvert fald $i$ en diasporakontekst) former af rutiniseret islamisk handlen (som at spise halalmad og at bære tørklæde) (Jacobson 1998). De seks praksisser er desuden anerkendt som centrale markører af islam blandt både muslimer og ikke-muslimer. De aktører, der er medtaget i spørgeskemaet som potentielt indflydelsesrige for håndtering af muslimsk praksis, er udvalgt på baggrund af resultaterne fra et forstudie bestående af interviews med en række forskellige skoleprofessionelle: lærere, skoleledere, tosprogslærere, tolke og integrationskonsulenter. Det samme gælder for skoleledernes forhold til religion og islam; disse reflekterer desuden teoretisk variation i forhold til, om religion/islam opfattes som kollektivt eller individuelt betydningsfuldt, om religion/islam opleves som havende positive eller negative effekter, og om religion/islam ønskes begrænset til eller udelukket fra bestemte dele af skolens sociale liv (Jensen 2013).

Interviewundersøgelsen består af interviews med ledere og ansatte fra ni skoler, der er udvalgt, således at meget forskellige skoler (i forhold til både håndtering af muslimsk praksis, geografisk placering og andel af elever med muslimsk baggrund) er repræsenteret. Dette brede materiale giver mulighed for at afdække generelle ligheder og forskelle i håndteringen af islam i skolerne, ligesom det giver mulighed for at undersøge, hvilke sammenhænge der er mellem skolernes håndtering og

\footnotetext{
3 Der er i dag langt færre folkeskoler på grund af lukninger og sammenlægninger. Spørgeskemaet blev sendt ud til samtlige folkeskoler. Svarprocenten var 27. Fordi spørgeskemapopulationen ikke er en tilfældigt udvalgt stikprøve, kan de generelle fordelinger ikke generaliseres til alle danske folkeskoler. Undersøgelsen er til gengæld velegnet til at identificere nogle overordnede tendenser, forskelle og sammenhænge imellem forskellige skolers forskellige håndtering af muslimsk praksis.

${ }^{4}$ Kun på de skoler, hvor der er elever med muslimsk baggrund, er skolelederne blevet bedt om at svare på, hvordan man på deres skole håndterer muslimsk praksis.
} 
de involverede aktører. Analysen tager udgangspunkt i det generelle overblik, som de kvantitative data frembringer, og benytter resultaterne fra interviewundersøgelsen til at understøtte en dybere forståelse af variationerne og nuancerne i skolernes håndtering af muslimsk praksis.

\section{Manglende overordnede retningslinjer}

I Danmark findes der som nævnt ikke nogen generelle retningslinjer for, hvordan muslimske praksisser, religiøs forskellighed eller religiøse minoriteter skal håndteres i folkeskolen. I 2003 udgav Undervisningsministeriet Inspiration til bedre integration $i$ folkeskolen - en form for inspirationskatalog, der byggede på konkrete skolers udvikling af løsninger på 'kulturelle og religiøse problemstillinger' (Undervisningsministeriet 2003). Selvom man på en del skoler med muslimske elever kender til Undervisningsministeriets inspirationskatalog, indikerer resultaterne af spørgeskemaundersøgelsen, at brugen af inspirationskataloget ikke har nogen effekt på skolernes overordnede håndtering af muslimsk praksis (Jensen 2013).

Nogle kommuner har udviklet retningslinjer for kommunens skoler $i$ forhold til $\mathrm{fx}$ fravær $\mathrm{i}$ forbindelse med højtider, og i Aarhus og København har man udfærdiget en folder, som skolerne kan uddele til børn og forældre i forbindelse med faste under Ramadanen (se fx Aarhus Kommune, ukendt udgivelsesår). Ifølge spørgeskemaundersøgelsen kender skoler fra 26 ud af de 89 kommuner, der er repræsenteret i undersøgelsen, til kommunalt udviklede retningslinjer for håndtering af muslimske praksisser. Sådanne retningslinjer synes dog ikke at have nogen generel effekt på skolernes håndtering af muslimsk praksis, og ifølge flere skoleledere følger man ikke slavisk kommunens retningslinjer, hvis man mener, at man på den enkelte skole har udviklet en bedre løsning (Jensen 2013). Det vil sige, at skolers håndtering af muslimsk praksis primært udvikles lokalt på den enkelte skole af de lokale aktører, der er en del af skolens nære kontekst.

\section{"Vi skal have det til at fungere"}

Den danske folkeskole har i kraft af sin statslige uddannelses- og opdragelsesopgave en stærk institutionel autoritet (Kampmann 2005). Det fremgår af interviewmaterialet, at ledere, lærere og pædagoger ikke er i tvivl om, at det er dem, der bestemmer over det, der foregår i skolen. Skolens autoritet omfatter et bredt område; den vedrører ikke kun den konkrete undervisning, men også interaktionen mellem eleverne, deres fysiske aktiviteter og endda deres helbredstilstand (Gilliam og Gulløv 2012). På sin vis omfatter skolens autoritet ethvert aspekt af elevernes liv, der har berøring med skolen. I den sammenhæng er det ikke så underligt, at de muslimske praksisser, der 'tages med ind i skolen', fx i form af piger, der går med tørklæde, og forældre, der ønsker deres børn fritaget fra undervisningen et par dage $i$ forbindelse med fejring af religiøse højtider, naturligt også reguleres af skolen. Som sådan er skolen ikke generelt udfordret af tilstedeværelsen af muslimske praksisser.

Det betyder dog ikke, at de muslimske børn og forældre ikke har nogen indflydelse. Som det illustreres i nedenstående citat fra skolelederen på Bundvadskolen, er det afgørende at finde en løsning, der tilfredsstiller begge parter: 
Vi har ikke en masse principper, som er nedskrevet. En gang imellem, når der opstår et problem, så tager vi det op og diskuterer, hvad der er mest hensigtsmæssigt. Det er jo ikke for at genere nogen, at de [eleverne] gør det, og det er ikke for at genere nogen, at vi siger, at sådan vil vi have det. Vi skal have det til at fungere. (Skoleleder på Bundvadskolen)

Citatet fra skolelederen på Bundvadskolen illustrerer også den manglende overordnede håndtering af muslimske praksisser som et selvstændigt område, skoler forholder sig til. Kategorien 'muslimske praksisser', som jeg har konstrueret og interesseret mig for, er med andre ord en fremmed kategori i skolen. Dette forhold afspejler sig også i den store forskel, der er mellem håndteringen af de forskellige muslimske praksisser, der er undersøgt. Som det fremgår af tabellen nedenfor, sørger størstedelen af skoler med elever med muslimsk baggrund for, at der til skolefester og lignende arrangementer serveres retter, som ikke indeholder svinekød. Til gengæld er det kun ganske få skoler, der har et lokale til de børn, som ønsker at bede.

\section{Tabel 1. Udbredelsen af konkrete eksempler på håndtering af muslimsk praksis i 286 skoler med muslimske elever}

Eksempel på håndtering af muslimsk praksis Procentdel af

Tager hensyn til fastende elever $\quad 42$

Fraråder faste $\quad 35$

Regler for fravær ved muslimske højtider $\quad 22$

Besøg i moske 21

Halalmad i hjemkundskab 12

Fraråder bøn $\quad 11$

$\begin{array}{ll}\text { Fremhæver muslimske højtider } & 7\end{array}$

Fraråder brug af tørklæde 3

Bederum 1

Fraråder kontakt til imam

Note til tabel 1. Procenten angiver, hvor mange af skolelederne på de 286 skoler med muslimske elever der er enige $\mathrm{i}$, at de angivne eksempler på håndtering af muslimsk praksis passer på deres skole. De konkrete udsagn, som skolelederne er blevet bedt om at vurdere, er de følgende: 'På vores skole sørger vi for, at der serveres alternativer til svinekød til skolearrangementer og lignende', 'skolen tager hensyn til de fastende børn $f x \quad i$ forbindelse med hjemkundskabsundervisningen eller idræt', 'vi fraråder eleverne at faste $i$ skoletiden', 'på vores skole har vi faste regler for, hvornår og hvor længe elever med muslimsk baggrund kan få fri i forbindelse med muslimske højtider', 'på vores skole har en eller flere klasser været på besøg i en moske', 'på vores skole anvender vi halalmad i undervisningen i hjemkundskab', 'på vores skole fraråder vi eleverne at bede i skoletiden', 'på vores skole har vi arrangeret aktiviteter i forbindelse med muslimske højtider, fx $\mathrm{i}$ form af en fest, et særligt tema for undervisningen eller lignende', 'på vores skole fraråder vi piger med muslimsk baggrund at gå med tørklæde', 'på vores skole har vi et lokale til de elever, som ønsker at bede', 'på vores skole fraråder vi eleverne at have kontakt til den lokale imam eller andre muslimske autoriteter'. 
Af interviewene fremgår det, at den meget forskelligartede håndtering af de forskellige praksisser er et resultat af flere faktorer. For det første afhænger håndteringen af en konkret praksis af, i hvor høj grad denne er vigtig for de muslimske elever og forældre, og om de udviser interesse for en bestemt håndtering. For det andet afhænger håndteringen af en konkret praksis af, i hvor høj grad denne praksis er i konflikt med skolens aktiviteter. $\mathrm{Og}$ for det tredje afhænger håndteringen af en konkret praksis af, i hvor høj grad den symbolske værdi, der tillægges denne praksis, er i overensstemmelse med skolens værdier.

Tager man tørklædet som eksempel, så er det ikke en praksis, der typisk møder modstand eller håndteres eksplicit i skolerne. Dette skyldes ikke, at ingen piger med muslimsk baggrund bærer tørklæde, men kun på halvdelen af de skoler, hvor der er piger med tørklæde, har man haft overvejelser om, hvordan tørklædet skal håndteres (Jensen 2013). En direkte håndtering af tørklædet etableres først i det tilfælde, at tørklædet er i konflikt med skolens aktiviteter, som fx i idrætsundervisningen, hvor meget store tørklæder opfattes som en sikkerhedsrisiko (man kan sidde fast og blive kvalt).

I sådanne tilfælde har man på flere skoler anbefalet forældrene at anskaffe 'sportstørklæder', dvs. kortere, tætsiddende tørklæder, som pigerne kan bruge i idræt. Tørklædet kan både fortolkes som symbol på personlig frihed og identitet i kraft af tilhørsforholdet til islam og som symbol på manglende ligestilling eller endda kvindeundertrykkelse (Asad 2006). Eksempler fra interviewmaterialet illustrerer, at den førstnævnte fortolkning af tørklædets symbolværdi som identitetsmarkør er fint i overensstemmelse med skolers værdier om individualitet, og tørklædet bliver således ikke frarådet. Omvendt er fortolkningen af tørklædet som symbol på undertrykkelse i modstrid med skolens idealer om ligestilling og personlig frihed.

Håndtering af muslimsk praksis - to generelle modeller

Det er naturligvis forskelligt fra skole til skole, hvordan muslimske praksisser helt præcist håndteres. Ifølge en konsulent på tosprogsområdet, der kommer på mange af landets skoler med elever med muslimsk baggrund, er der ligeså mange måder at håndtere muslimsk praksis på, som der er skoler. Analysen af spørgeskemamaterialet ${ }^{5}$ demonstrerer dog, at der blot er to væsentlige dimensioner, som skoleledernes svar fordeler sig i forhold til. De fællestræk blandt spørgeskemasvarene, som kendetegner de to dimensioner, kan overordnet set karakteriseres som hhv. inkluderende og ekskluderende håndteringer af muslimsk praksis. I analysen benyttes dimensionerne til at etablere skalaer, der gør det muligt at sammenligne forskellige niveauer af inkluderende/ekskluderende håndtering på skolerne og til at undersøge, om der er en generel sammenhæng mellem disse niveauer og indflydelse fra udvalgte lokale aktører (elever, forældre, kommune) eller skoleledernes forestillinger om religion og islam.

${ }^{5}$ I det konkrete tilfælde er der tale om en faktoranalyse af de forskellige eksempler på håndtering af muslimsk praksis, som skolelederne har forholdt sig til (Jensen 2013). 
Den inkluderende håndtering er kendetegnet ved at indarbejde muslimske praksisser som en naturlig del af det daglige skoleliv, fx ved at etablere faste retningslinjer for, hvornår og hvor længe man kan få fri ved muslimske højtider, ved at benytte halalmad i undervisningen $\mathrm{i}$ hjemkundskab og ved at arrangere besøg i en moske i forbindelse med undervisningen.

Vi har ikke ønsket, at vores lærere skulle stå og tage stilling til det i deres undervisning. Så vi har sagt, at der ikke er nogen, der tager skade af at spise halalslagtet kød, men der er nogen, der tager skade af ikke at spise halalslagtet kød. Jeg synes, at vi gennem dialog er landet på en god ordning. (Skoleleder på Egelundskolen)

Som det fremgår af ovenstående citat fra skolelederen på Egelundskolen og af de øvrige interviews med skoleledere, knyttes den inkluderende form for håndtering til opfattelsen, at de enkelte muslimske praksisser er af afgørende betydning for de muslimske elever - de 'tager skade' af ikke at spise halalslagtet kød. Som sådan udtrykker de muslimske praksisser vigtige behov, som eleverne har, og derfor skal de - ifølge skolens ideal om inklusion - inkluderes som et hvilket som helst andet særligt behov, eleverne måtte have.

Den ekskluderende håndtering af muslimsk praksis er kendetegnet ved $\mathrm{fx}$ at fraråde eleverne at gå med tørklæde, at faste eller at bede $\mathrm{i}$ skoletiden. I interviews med skolelederne fremgår det, at det er en særlig form for religiøse udtryk, der ikke er velkomne i skolen. Som skolelederen på Kirseskolen formulerer det: "Vi har ind imellem børn, som siger, at de ikke vil have noget kød, fordi der har været svinekød på panden tidligere. Der er ingen nåde dér, der siger jeg stop. Der er man ude i det fundamentalistiske ærinde”. Flere skoleledere gør desuden opmærksom på, at det ikke er særligt muslimske praksisser, der ikke er velkomne; det er alle religiøse udtryk, der har en ekstrem eller missionerende karakter.

\section{Usynlige eller synlige muslimske praksisser}

En af de helt afgørende aktører i skolers udvikling af håndtering af muslimsk praksis er de muslimske elever. Det fremgår tydeligt af analysen ad spørgeskemamaterialet, at andelen eller koncentrationen af muslimske elever på den enkelte skole er tæt forbundet til skolens håndtering af muslimsk praksis. Eller mere præcist: Der er en klar sammenhæng mellem andelen af muslimske elever og niveauet af inkluderende håndtering, mens der ikke er nogen sammenhæng mellem andelen af muslimske elever og niveauet af ekskluderende håndtering. Dette resultat er interessant i flere sammenhænge.

På langt de fleste folkeskoler udgør de muslimske elever kun en ganske lille minoritet (Sedgwick 2010). I den undersøgte population har omkring 80 procent af skolerne med muslimske elever 20 procent eller færre af sådanne elever. På disse skoler er der generelt et lavt niveau af inkluderende håndtering af muslimske praksisser. Dette afspejler den generelle mangel på overordnet håndtering af muslimske praksisser på skoleniveau - det er i højere grad op til den enkelte lærer selv at finde løsninger, hvis der opstår en konkret situation, som vedrører muslimske praksisser. Den manglende overordnede håndtering af muslimsk praksis 
skyldes, at de muslimske praksisser i vid udstrækning er 'usynlige', når de muslimske elever er få. Skolelederne er $\operatorname{dog} i$ en vis udstrækning opmærksomme (eller bliver opmærksomme over tid) på muslimske praksisser, fordi de kan være kilde til udfordringer for skolen eller i det mindste for den enkelte lærer, der har med de muslimske elever at gøre. Sådanne udfordringer er ofte knyttet til en usikkerhed i forhold til at bestemme over elevers religiose praksisser. Som skolelederen på Røgbækgade Skole beskriver det, så er det svært at håndtere noget, som man ikke ved noget om (islam/muslimsk praksis), men som man gerne vil respektere, samtidig med at man skal have skolen til at fungere og introducere eleverne til et liv 'på danske vilkår'.

(...) det kunne være rigtig godt, at der var nogle, der sagde, at de havde den rigtige viden. Det ville være dejligt, hvis nogle sagde, at det her mener vi, er det rigtige. Og så kunne vi diskutere ud fra det. I Danmark er vi så flinke, at vi forstår alle folk. Og hvis folk ikke tror, de kommer i himlen, fordi det ene eller det andet, så respekterer vi selvfølgelig det. (...) Jeg tænker, at hvor meget kommer man i helvede, og hvor meget kommer man ikke i himlen - det vil vi jo selvfølgelig ikke genere, men omvendt så kan vi jo også sige, at vi nu er i et samfund, hvor det ikke er i orden at blive hjemme, når der er ramadan. Det er ikke lovlig grund. (Skoleleder på Røgbækgade Skole)

På skoler, hvor der er flere børn med muslimsk baggrund, er der typisk udviklet fælles skolepraksisser for håndteringen af i hvert fald nogle af de muslimske praksisser. Flere skoleledere nævner i den sammenhæng, at de ikke ønsker at lærerne skal stå $\mathrm{i}$ undervisningssituationen og tage principiel stilling til muslimske praksisser, fordi det fjerner fokus fra netop undervisningen.

\section{Aktørerne i den lokale skolekontekst}

Ingen af de øvrige aktører i den lokale skolekontekst har så afgørende betydning for håndteringen af muslimsk praksis som koncentrationen af muslimske elever. Hvad angår forældrene til de muslimske børn, så har det ingen generel effekt på skolens håndtering, at sådanne forældre fx er valgt ind i skolebestyrelsen (Jensen 2013). Til gengæld har skoler, der aktivt har inviteret de muslimske forældre til at deltage $i$ at udvikle skolens håndtering, en lidt mere inkluderende praksis end skoler, der ikke har inviteret forældrene (ibid.). Således spiller de muslimske forældre ofte rollen som forbandlere $\mathrm{i}$ udviklingen af skolens håndtering af muslimsk praksis: Når skolen anerkender forældrene som autoriteter i forhold til børnenes opfattelse af muslimske praksisser, inviteres de ind med henblik på at få lavet en løsning, som både skole og forældre bakker op om.

De skoleledere, der har besvaret spørgeskemaundersøgelsen, placerer generelt set skolelederen centralt i skolens udvikling (eller mangel på samme) omkring håndtering af muslimske praksisser. Næsten 80 procent af de deltagende skoleledere på skoler med muslimske elever vurderer, at skolelederen har indflydelse på skolens håndtering af muslimsk praksis (se tabel 2 nedenfor). 
Tabel 2. Udbredelsen af forskellige aktørers indflydelse på skolers håndtering af muslimsk praksis i 286 skoler med muslimske elever

\begin{tabular}{lr}
$\begin{array}{l}\text { Aktører med indflydelse på skolers } \\
\text { håndtering af muslimsk praksis }\end{array}$ & $\begin{array}{r}\text { Procentdel af } \\
\text { skoler }\end{array}$ \\
\hline Skoleleder & 78 \\
Tolk, skole-hjem vejleder eller & 46 \\
integrationskonsulent & \\
Muslimske forældre & 40 \\
Andre skoler & 31 \\
Integrations- eller Undervisningsministeriet & 30 \\
Kommune & 24 \\
Skolebestyrelse & 23
\end{tabular}

Note til tabel 2. Procenten angiver, hvor mange af skolelederne på de 286 skoler med muslimske elever der svarer ja til, at de angivne aktører har været en del af skolens udvikling af håndteringen af muslimsk praksis på deres skole.

Skolelederen er ifølge interviewmaterialet den, der tager initiativet til at etablere en fælles 'skole-politik' i forhold til den ene eller den anden muslimske praksis. Et sådan initiativ er oftest en reaktion på en henvendelse fra lærere, forældre eller elever, der oplever et behov for en mere overordnet håndtering. Skolelederen har ofte rollen som mediator mellem forskellige interesser: elevernes, lærernes, forældrenes, kommunens, politikernes, Undervisningsministeriets, mediernes etc., og står som sådan alene mellem alle disse interesser, der skal balanceres. Skolelederne vælger $i$ nogle tilfælde at lægge beslutninger om håndteringen af muslimsk praksis over i skolebestyrelsen, men ofte støtter skolelederen sig til de forskellige 'specialister', der på den ene eller anden måde har et større kendskab til muslimsk praksis. Sådanne specialister omfatter både tolke, tosprogslærere, skole-hjem vejledere, integrationskonsulenter og ansatte lærere med muslimsk baggrund. Disse forskellige specialister fungerer som leverandorer af håndtering, fordi de med deres særlige viden leverer 'autoritative løsninger' til skolelederen.

Dette fremgår $\mathrm{fx}$ af nedenstående citat fra skolelederen på Markvejskolen, der sammen med skolebestyrelsen får hjælp af en integrationskonsulent til at håndtere nogle elevers ønske om et bederum på skolen.

Så vi valgte strategien at tage det i skolebestyrelsen, og de valgte strategien at indkalde en konsulent fra forvaltningen, som sagde hårdt "nej, det er altså ikke noget, som vi går ind for her $i$ kommunen". Og så blev den lukket på den måde, fordi nogen tog ansvaret. Og det var fint, for sådan som jeg forstod pigerne, så må man acceptere som troende, at der er nogle ting, som gør, at man ikke kan bede. (Skoleleder på Markvejskolen)

Det er ganske interessant, at analysen af spørgeskemamaterialet afslører en svag, men entydig sammenhæng mellem den ekskluderende form for håndtering af muslimsk praksis og skolens brug af forskellige specialister. Dette resultat indikerer, at specialisterne bidrager med den nødvendige 
autoritet og viden, som kræves for ikke kun at inkludere og regulere, men også at sætte mere direkte grænser for muslimsk praksis i skolen. Som læseren måske allerede har bemærket, spiller de forskellige aktører deres sædvanlige eller naturlige rolle $\mathrm{i}$ skolen $\mathrm{i}$ forhold til udviklingen af håndteringen af muslimsk praksis. Undervisningsministeriets og kommunens retningslinjer udgør den sædvanlige ramme for skolens virke, eleverne er de naturlige objekter for skolens uddannelsesformål, forældrene er de naturlige forhandlere $i$ forhold til den opdragelsesopgave, de deler med skolen, skolelederen er den naturlige mediator mellem skolens mange interessenter, og specialisterne er de sædvanlige leverandører af autoritet og know-how.

Håndteringen af muslimsk praksis er som sådan ikke et selvstændigt domæne, som håndteres efter særlige principper, eller hvor de involverede aktører tildeles nye roller, de ikke ellers har. Selvom dette kan synes at være i modstrid med den tidligere beskrevne usikkerhed i forhold til at håndtere netop religiose praksisser, så illustrerer den manglende markering af muslimske praksisser som et særligt 'håndteringsområde' en i skolerne udbredt religionsforståelse, som jeg vil præsentere og diskutere i de følgende afsnit.

\section{Den 'sekulære' danske folkeskole}

Når der i temaet for denne udgave af TIFO er sat gåseøjne omkring folkeskolen som 'sekulær', er det med reference til alle de folkekirkelige traditioner, der fylder meget $\mathrm{i}$ undervisningen og naturligt markerer skoleårets gang, for slet ikke at tale om det tætte samarbejde der i hvert fald på nogle skoler er med den lokale præst, indlejringen af konfirmationsforberedelse i undervisningstiden, og den obligatoriske undervisning i kristendomskundskab på alle klassetrin. På trods af disse forbindelser mellem skole og en bestemt religion - den folkekirkekristne - er der blandt skoleprofessionelle en stærk selvforståelse af skolen som en sekulær institution. Denne forståelse knytter sig både til skolens uddannelsesformål, i forhold til hvilket religion betragtes som irrelevant, og til skolen som religiøst neutral og derfor i stand til at uddanne elever uanset deres religiøse tilhørsforhold eller mangel på samme.

I løbet af den forundersøgelse, der var med til at definere forskningsspørgsmålene for spørgeskema- og interviewundersøgelsen, har jeg mødt både undren og modstand blandt skoleprofessionelle, når jeg præsenterede min interesse for religion. Selvom jeg anerkender, at skoler primært interesserer sig for elevers faglige og sociale kompetencer og udvikling, var der i forundersøgelsen dog også indikationer på, at netop forestillinger om, hvordan religion bør håndteres, hvad der er religion, og hvad der ikke er religion, var i spil i skolernes overvejelser om håndteringen af muslimsk praksis. Derfor har jeg også specifikt interesseret mig for skolelederes opfattelser af religion og islam, og hvad de mener, er det rette forhold mellem skole og religion. Forestillinger om religion og idealer om, hvordan religion skal relatere sig til skolen, er i sig selv et stort og interessant område. I denne sammenhæng tegner jeg de helt overordnede linjer med det formål at konkludere $\mathrm{i}$ forhold til betydningen af sådanne forestillinger for håndteringen af muslimsk praksis. 


\section{Forestillinger om religion og islam}

En central pointe i forhold til skoleledernes forestillinger om islam og religion er, at sådanne forestillinger generelt set er både uartikulerede og ureflekterede. Ifølge skoleledernes svar på spørgeskemaundersøgelsen oplever de sjældent hverken religion eller islam i skolen på sådan en måde, at de har overordnede forestillinger om, hvad religion og islam er, eller hvilken funktion det har i skolen. Således er den mest udbredte forestilling blandt skolelederne om både religion og islam ganske enkelt, at religion/islam er et personligt anliggende, der kun vedrører den enkelte elev, som ikke har noget at gøre med elevens virke i skolen, og som derfor er irrelevant. Denne opfattelse af religion og islam synes at bevirke, at de traditioner og praksisser, som kommer til udtryk i skolen, ikke opfattes som religiøse eller som udtryk for religion/islam. Eller sagt på en anden måde: Fordi skolen opfattes som en sekulær institution, bliver alle aktiviteter i skolen også forstået som sekulære, eller i det mindste bliver ikke-sekulære aktiviteter usynlige eller umarkerede.

Der er dog en mindre gruppe af skolelederne, som har oplevet islam som betydningsfuldt for en del af de muslimske børn, og som har udviklede forestillinger om, hvordan islam kommer til udtryk i skolen. Karakteristisk for disse forestillinger er, at de ikke er entydigt hverken positive eller negative. Det vil sige, at forestillinger om islam som en kilde til identitet og som en markør af en særlig kulturel baggrund går hånd i hånd med forestillinger om islam som et system af regler eller forventninger, der kan være svære for børnene at kombinere med skolens forventninger til at være en 'god elev'. Denne sidste forestilling illustreres i nedenstående citat fra skolelederen på Bundvadskolen.

Ja, det er jo eleverne, som kommer ind i et krydsfelt, fordi de står med forældrenes forventninger. Det er jo ikke tilfældigt, at børnene begynder at sige, at de gerne vil faste. Selvfølgelig vil de gerne efterligne deres forældre, og de ved også godt, at der ligger nogle forventninger til, at de på et tidspunkt skal. Og så står de her med vores forventninger, fordi de godt ved, hvad vi synes om det her. Så det er jo eleverne, som er i klemme, så derfor skal vi også træde varsomt, når vi går ind og siger, at de skal være med i idræt alligevel. Det ved de godt, at de skal, men samtidig får de et problem, da de ikke kan drikke vand, fordi forældrene forventer, at sådan er det. Så eleverne står nogle gange i en presset situation. (Skoleleder på Bundvadskolen).

Analysen af skoleledernes forestillinger om islam og deres forestillinger om religion generelt afslører et par interessante sammenhænge imellem disse. For det første er skoleledere, der primært er positivt indstillede over for religion generelt, også positivt indstillede over for islam. De positive forestillinger om religion og islam består $i$ anerkendelsen af religion/islam som en vigtig både kollektiv og individuel ressource for eleverne. Modsat står negative forestillinger om religion alene og er ikke knyttet til negative forestillinger om islam. Generelt synes negative forestillinger om islam at være stort set fraværende blandt skolelederne. Der er ikke nogen entydig forklaring på denne sammenhæng, bortset fra at det måske er 'lettere' at være generelt negativt indstillet over for 'al 
religion' end det er at være negativt indstillet over for islam, der trods alt refererer til en bestemt gruppe mennesker/elever. Denne fortolkning stemmer i det mindste overens med mange skoleprofessionelles afstandstagen - særligt udbredt blandt dem, der har med mange muslimske elever at gøre - til debatten om islam og muslimer i Danmark, som kritiseres for at være entydigt negativ og ufrugtbar (Kühle 2011). De negative forestillinger om religion består primært i bevidstheden om religioners generelle konfliktpotentiale.

Principper for relationen mellem skole og religion

Skolelederne har generelt lettere ved at forholde sig til, hvilke principper der bør være styrende for relationen mellem skole og religion, end de har ved at forholde sig til oplevelser af islam og religion. Analysen af skoleledernes tilslutning til forskellige idealer om skole-religion relationen antyder, at skolelederne er opmærksomme på forskellige niveauer af en sådan relation. Størstedelen af skolelederne tilslutter sig, hvad jeg har defineret som neutralitetsprincippet, som primært vedrører forholdet mellem skolen og religiøse institutioner. ${ }^{6}$

Neutralitetsprincippet forbinder de både overlappende og delvist modstridende idealer om ligebehandling af alle religioner i skolen, om skolen som religiøst neutral og om skolen som helt adskilt fra religion. Særligt interessant ved neutralitetsprincippet er måske, at det strider imod de faktiske forhold i folkeskolen, der netop er forbundet til en bestemt religiøs institution - folkekirken. Neutralitetsprincippet aktiveres blandt flere af de interviewede skoleledere, når de beskriver deres overvejelser om muslimske elevers deltagelse i aktiviteter, som knytter an til kristendom og folkekirke.

Jeg registrerer udviklingen og prøver at finde ud af, om jeg kan skubbe i nogle retninger, som jeg synes er rimelige. Jeg ville ønske, at det ikke hed kristendomskundskab. Jeg ville ønske, at skole og kirke ikke hænger sammen på samme måde, som de gør nu. Jeg synes ikke, at der er respekt for den mangfoldighed - ikke kun $i$ forhold til muslimske børn, men også fordi vi er så forskellige - vi har forskellige tilgange til det religiøse. (Skoleleder på Markvejskolen)

Netop forbindelsen mellem skolen og folkekirken bliver problematiseret af flere skoleledere, der har svært ved at forsvare denne forbindelse både over for dem selv og de elever og forældre, fx de muslimske, der ikke har nogen relation til folkekirken.

En mindre del af skolelederne tilslutter sig omsorgsprincippet, der primært vedrører relationen mellem skolen og elevers religion. Omsorgsprincippet forbinder idealerne om skolens hensyntagen til elevernes religiøse praksisser og skolens støtte af elevernes frihed til at praktisere deres religion. I interviewmaterialet aktiveres

\footnotetext{
${ }^{6}$ De principper, der beskrives i dette afsnit, er udviklet på baggrund af en faktoranalyse af de forskellige idealer for relationen mellem skole og religion, som skolelederne har forholdt sig til.
} 
omsorgsprincippet af skoleledere, som anerkender betydningen af islam for nogle elever, og som ønsker at respektere elevens oplevelser af, hvad der tilladt for ham eller hende. Flere skoleledere nævner eksempler på, at specielt yngre elever kan være decideret bange for, hvad der sker, hvis de fx spiser noget forkert, og disse skoleledere er meget opmærksomme på, at skolen respekterer sådanne grænser, som eleven har. Et eksempel på en meget aktiv forfølgelse af omsorgsprincippet leveres af skolelederen på Bundvadskolen:

(...) jeg har oplevet en lærer, som skulle på lejrskole, hvor der var en elev, der ikke måtte komme med, for så kunne han ikke finde ud af, hvor Mekka var. Og der var en meget handlekraftig dame, der drog hjem til forældrene med et kompas i hånden. Hun ville gerne være garanten for, at hun fandt retningen mod Mekka. Hvis han tog sit bedetæppe med, så skulle hun nok sørge for, at der var et fredeligt sted. Det accepterede forældrene, og hun gennemførte det. Drengen var lykkelig. (Skoleleder på Bundvadskolen)

Som nævnt ovenfor har jeg interesseret mig for skolelederes forestillinger om religion og islam og deres principper for forholdet mellem skole og religion, fordi jeg forventede, at sådanne forestillinger og principper ville hænge sammen med skolers håndtering af muslimsk praksis. Analysen af spørgeskemamaterialet viser dog, at det stort set ikke er tilfældet. Særligt forestillingerne om religion og islam synes helt uafhængige af håndteringen af muslimsk praksis.

Der er en svag sammenhæng mellem afvisning af omsorgsprincippet og svagt højere niveauer af ekskluderende håndtering af muslimsk praksis. Det vil sige, at man på skoler, hvor skolelederen ikke mener, at det er skolens opgave at tage hensyn til elevers religiøse praksisser eller mere generelt at støtte elevernes frihed til at praktisere deres religion, i højere grad fraråder muslimske praksisser i skolen. Det betyder igen, at skolelederes manglende tilslutning til omsorgsprincippet er en del af men ikke hele - forklaringen på, hvorfor man på nogle skoler fx fraråder faste og bøn i skolen.

Skolelederne er primært optagede af at 'få det til at fungere', og håndteringen af muslimsk praksis udvikles pragmatisk, når behovet opstår (jf. også Gilliam i dette temanummer og 2009). Håndteringen af muslimsk praksis er kun ideologisk styret i den forstand, at håndteringen $i$ store træk følger den generelle skoleideologi om inklusion. De begrænsninger, der er for udøvelsen af muslimske praksisser, er delvist ideologisk betingede, men også pragmatiske i den forstand, at nogle praksisser - fx fasten - særligt udfordrer skolens undervisningsformål. Med denne primært pragmatisk udviklede håndtering af muslimsk praksis er det tillokkende at konkludere, at forestillinger om og principper for religion er uden betydning. Der synes dog at være en implicit sammenhæng, som den direkte analyse ikke afslører: Præcis fordi muslimske praksisser generelt ikke primært opfattes som udtryk for religion eller islam, bliver de ikke håndteret i overensstemmelse med de forestillinger eller principper, som skolelederne har på dette område. Den fremherskende opfattelse af religion som irrelevant og personlig er således selve grundlaget for skolernes udbredte opfattelse af muslimske 
praksisser som noget, der håndteres på linje med andre særlige behov, som skolen forsøger at inkludere.

\section{Konklusion: Autoritet, inklusion og religion}

De danske debattørers bekymring for, om danske traditioner tvinges ud af danske institutioner, afspejles generelt ikke i folkeskolers håndtering af muslimsk praksis. For det første er skolernes autoritet $i$ form af at udstikke retningslinjer for, hvad der er tilladt eller tilrådeligt i skolen, så stærk og selvfølgelig, at den ikke udfordres nævneværdigt af eventuelle krav om tilpasning til muslimsk praksis. Sådanne krav er for det andet stort set fraværende, og måske netop derfor synes bekymringen om, at 'danske traditioner' er udfordret, ikke at være fremherskende blandt skolelederne. For det tredje er man på de mange skoler, hvor der kun er få muslimske elever, generelt set ikke opmærksom på muslimsk praksis som et område, der bør håndteres. Når islam eller muslimske praksisser ikke opfattes som noget, der kan komme til udtryk i skolen, håndteres det heller ikke eksplicit. Denne form for ureflekteret håndtering er på sin vis den tydeligste markering af skolens autoritet $i$ form af at kunne definere, hvilke aktiviteter/interesser der er synlige og hensynskrævende, og hvilke der ikke er.

Andre debattørers bekymring for, at muslimers religiøse frihed krænkes, kan synes berettiget efter ovenstående beskrivelse af skolens autoritet til potentielt at definere muslimsk praksis som usynlig i skolen. I den sammenhæng er det værd at bemærke, at denne autoritet er et grundlæggende vilkår, som alle elever - muslimske som ikke muslimske må forholde sig til. Skolens autoritet udfordres desuden løbende af eleverne. I den sammenhæng bruger eleverne alle midler, også deres muslimske praksisser.

En skoleleder, der deltog i studiets forundersøgelser, fortalte eksempelvis om tre muslimske piger $\mathrm{i}$ første klasse, som midt $\mathrm{i}$ en musiktime pludselig forlod lokalet, fordi der blev sunget en julesalme, hvor navnet Jesus blev nævnt. Pigernes forældre var uforstånde over for deres adfærd, der derfor af skolen blev opfattet som en udfordring af musiklærerens autoritet over klassen (Jensen og Kühle 2013). Det er i sådanne tilfælde, at skoleledere og lærere - særligt på skoler hvor man ikke har erfaring med elever med anden religiøs baggrund - er udfordrede $\mathrm{i}$ forhold til at vurdere, hvad de skal stille op med elevernes ønsker om særlige hensyn: Er disse ønsker udtryk for reelle bekymringer eller behov, som eleverne har, eller er de del af en autoritetsudfordring, eller måske middel til at opnå særlige fordele? Spørgsmålet om håndteringen af muslimsk praksis er i den forstand også - men ikke udelukkende - et spørgsmål om autoritet.

Den brede inklusion af muslimske praksisser, der kendetegner skoler med en betydelig andel af muslimske elever, synes at være en naturlig udvidelse af skolens generelle inklusionsideal. Inklusionen af de muslimske praksisser i skolens hverdagsliv markerer en erkendelse fra skolens side af disse praksisser som både synlige og relevante for eleverne, selvom betydningen af 'islam' som sådan ikke nødvendigvis anerkendes. Der er i højere grad tale om, at de skoleprofessionelle er opmærksomme på, hvad der er vigtigt for børnene, og at de viser omsorg for det. Som nævnt ovenfor er inklusionen af muslimsk praksis 
ikke grænseløs, heller ikke på skoler hvor de muslimske elever udgør flertallet. Grænserne for inklusion er både defineret af, hvad der praktisk er muligt, og hvad der er foreneligt med skolens værdier. I den sammenhæng aktiveres værdier om, hvilke former for religiøse udtryk der kan artikuleres i skolen. Det er en forudsætning for inklusionen af muslimske praksisser, at de ikke kommer til udtryk på en missionerende, 'ekstrem' eller alt for 'religiøs' måde.

Selvom mange skoleledere synes at have en nuanceret forståelse af islam og elever med muslimsk baggrund, er deres håndtering af muslimske praksisser og deres forståelser af religion alligevel på sin vis paradoksal. Nærværende studie har demonstreret, at mange skoleledere har en ret snæver forståelse af religion. Det vil sige, at det kun er ganske få fænomener, hvis nogen overhovedet, de opfatter som udtryk for religion. Det er disse få fænomener, $\mathrm{fx}$ bøn, mission eller overdrevne (ekstreme/fundamentalistiske) overbevisninger, der er uvedkommende i skolen. Konkrete børns konkrete ønsker om halalmad opfattes ikke som udtryk for denne uønskede form for religion, og derfor kan det let imødekommes i skolen.

Det paradoksale består $i$, at det netop er de skoleprofessionelles oplevelse af, at disse praksisser er betydningsfulde og i nogle tilfælde ufravigelige for børnene, der tilskynder de skoleprofessionelle til at imødekomme børnenes ønsker. Og børnene synes netop at kategorisere disse praksisser som betydningsfulde og ufravigelige, fordi de har at gøre med religion eller islam - et domæne, hvor tingene i børnenes forståelse ikke er til diskussion, og hvor overtrædelser har alvorlige konsekvenser.

Den manglende sammenhæng mellem skolelederes opfattelser af religion og islam og skolers håndtering af muslimsk praksis, som dette studie har vist, kan dermed ikke benyttes som argument for, at skolers håndtering af muslimsk praksis ikke er influeret af forestillinger om religion og islam. De forestillinger, som er betydningsfulde, er bare ikke de forventede. Det handler således ikke om hvorvidt islam eller religion opfattes som fx godt eller skidt eller kollektivt eller individuelt signifikant. Det handler snarere om, hvorvidt de muslimske praksisser overhovedet opfattes som 'egentligt religiøse'. Den 'sekulære' danske folkeskole er i den forstand kendetegnet ved en særlig form for 'sekularisme' hvor kun ganske få muslimske praksisser opfattes som så religiøse, at de ikke kan tillades i skolen. Netop på baggrund af denne sekularisme, kan langt de fleste muslimske praksisser inkluderes i, tilpasses til og begrænses af skolens daglige liv.

\section{Forfatterpræsentation}

Sidsel Vive Jensen er ph.d. i religionssociologi og ansat som forsker på KORA, Det Nationale Institut for Kommuners og Regioners Analyse og Forskning. Sidsel interesserer sig særligt for forholdet mellem religion og offentlige institutioner. Hendes ph.d.-afhandling 'It has nothing to do with religion. Governance of Muslim practices in Danish public schools' fra 2013 behandler netop religiøse (muslimske) praksisser i folkeskolen. 


\section{Referencer}

Aarhus Kommune, ukendt udgivelsesår: Faste $i$ Ramadanen og Borns Skolegang.

Andersen, Peter B., Curt Dahlgren, Steffen Johannesen og Jonas Otterbeck (red.), 2006: Religion, Skole og Kulturel Integration $i$ Danmark og Sverige, Museum Tusculanums Forlag, København.

Asad, Talal, 2006: "Trying to understand French secularism", i: Hent de Vries og Lawrence E. Sullivan (red.): Political Theologies: Public Religions in a Post-Secular World, Fordham University Press, USA.

Anderson, Sally, 2008: Civil Sociality: Children, Sport, and Cultural Policy in Denmark, Information Age Pub Incorporated, USA.

Bader, Veit, 2007: "The governance of Islam in Europe: The perils of modelling", i: Journal of Ethnic and Migration Studies, 33 (6).

Botvar, Pål Ketil and Trygve Wyller, 2009: "Unge religiøse har radikale ideer", Aften 7 April 2009: 14.

Bowen, John, 2007: "A view from France on the internal complexity of national models", i: Journal of Ethnic and Migration Studies, 33 (6)

Buchardt, Mette, 2008: Identitetspolitik i Klasserummet: 'Religion' og 'Kultur' som Viden og Social Klassifikation: Studier $i$ et Praktiseret Skolefag, Det Humanistiske Fakultet, Københavns Universitet.

Ekstra Bladet 15. juli 2013. "Børnehaver bandlyser svinekød".

Ekstra Bladet 21. juli 2013. "Hospital indfører halalkød".

Fetzer, Joel S., and J. Christopher Soper, 2005: Muslims and the State in Britain, France, and Germany, Cambridge University Press, Cambridge.

Gilliam, Laura, 2009: De Umulige Born og det Ordentlige Menneske: Identitet, Ballade og Muslimske Fallesskaber Blandt Etniske Minoritetsborn, Aarhus Universitetsforlag, Aarhus.

Gilliam, Laura og Eva Gulløv, 2012: Civiliserende Institutioner. Om Idealer og Distinktioner $i$ Opdragelse, Aarhus Universitetsforlag, Aarhus.

Information 14. juni 2003. "Ikke minister for leverpostej".

Ihle, Annette Haaber, 2007: Magt, Medborgerskab og Muslimske Friskoler i Danmark. Traditioner, Idealer og Politikker, Institut for Tværkulturelle og Regionale Studier, Københavns Universitet.

Jacobson, Jessica. 1998. Islam in Transition: Religion and Identity among British Pakistani Youth, Routledge, London.

Jeldtoft, Nadia J., 2012: Everyday Lived Islam. Religious Reconfigurations and Secular Sensibilities among Muslim Minorities in the West, ikke udgivet ph.d.-afhandling, Det Teologiske Fakultet, Københavns Universitet.

Jensen, Sidsel Vive, 2013: It has Nothing to do With Religion. Governance of Muslim Practices in Danish Public Schools, ikke udgivet ph.d.-afhandling, Institut for Kultur og Samfund, Aarhus Universitet.

Jensen, Sidsel Vive og Lene Kühle, 2013: “'School Islam’: Lived religion in the context of a secular public institution", i: Nathal Dessing, Nadia Jeldtoft og Linda Woodhead (red.): Everyday lived Islam in Europe, Ashgate, Hampshire.

Jensen, Tim, 1994: Islam i Skolen: En Undersogelse af Fremstillingen af Islam $i$ Bestemmelser og Lareboger Beregnet for Folkeskolen, Gymnasieskolen og HF, Danmarks Lærerhøjskole, København.

Kampmann, Jan, 2005: "Understanding and Theorizing Modern Childhood in Denmark: Tendencies and Challenges", i: Birgitte Tufte, Jeanette Rasmussen og Lars Bech Christensen (red.): 
Frontrunners or Copycats?, Copenhagen Business School Press, København.

Kühle, Lene 2014: "Religious Diversity and Muslim Claims-Making: Conflicts over the Danish Folkeskole", i: Mark Sedgwick (red.) Making European Muslims. Religious Socialization among Young Muslims in Scandinavia and Western Europe, Routledge, London.

Liederman, Lina Molokotos, 2000: "Pluralism in education: The display of Islamic affiliation in French and British schools", i: Islam and Christian-Muslim Relations, 11 (1).

Mannitz, Sabine, 2004: "The place of religion in four civil cultures”, i: W. Schiffauer, Gerd Baumann, R. Kastoryano, and S. Vertovec (red.): Civil Enculturation. Nation-state, School and Ethnic Difference in the Netherlands, Britain, Germany and France, Berghahn Books, New York.

Maussen, Marcel, 2007: The Governance of Islam in Western Europe. A State of the Art Report, IMISCOE, 16.

Moldenhawer, Bolette, 2001: En Bedre Fremtid? Skolens Betydning for Etniske Minoriteter, Hans Reitzels Forlag, København.

Olesen, Aste, 1987: Islam og Undervisning i Danmark, Aarhus Universitetsforlag, Aarhus.

Rath, Jan et al., 2001: Western Europe and its Islam, Brill, Leiden.

Salvatore, Armando, 2007: "Authority in question: Secularity, republicanism and 'communitarianism' in the emergent Euro-Islamic public sphere", i: Theory, Culture and Society, Vol 24, no 2, pp. 135-160.

Sedgwick, Mark, 2010: Pupils of Muslim Cultural Origin in Danish Schools, ikke udgivet forskningsnotat, Institut for Kultur og Samfund, Aarhus Universitet.

Shakoor, Talat, 2008: "Formål for muslimske friskoler i Danmark udviklinger i formålserklæringer og vedtægter for danske friskoler for muslimske børn", i: Tidsskrift for Islamforskning, nr. 3: 29-43.

Sunier, Thijl, 2009: Beyond the Domestication of Islam. A Reflection on Research on Islam in European Societies, Faculteit der Sociale Wetenschappen van de Vrije Universiteit, Amsterdam.

Tatari, Eren, 2009: "Theories of the state accommodation of Islamic religious practices in Western Europe", i: Journal of Ethnic and Migration Studies, nr. 35(2): $271-288$.

Undervisningsministeriet, 2003: Inspiration til Bedre Integration $i$ Folkeskolen.Ahlberg, Nora, 1990: New Challenges_-Old Strategies. Themes of Variation and Conflict among Pakistani Muslims in Norway. Finish Anthropological Society, Helsinki. 
